\title{
Combining ability analysis in linseed (Linum usitatissimum L.) for improvement of seed yield and its component traits
}

\author{
Vivek Kumar Singh ${ }^{1 *}$, Vijay Sharma ${ }^{2}$, Mohit Chaudhary ${ }^{1}$, Sunil Kumar Paswan ${ }^{4}$, Azad \\ Ahmad $^{1}$, Moolchandra Verma ${ }^{3}$ and M. P. Chauhan ${ }^{1}$ \\ ${ }^{1}$ Department of Genetics \& Plant Breeding, N.D. University of Agriculture \& Technology, Faizabad - 224 229, INDIA \\ ${ }^{2}$ Department of Genetics \& Plant Breeding, Maharana Pratap University of Agriculture \& Technology, Udaipur - \\ 313 001, INDIA \\ ${ }^{3}$ Department of Vegetable Science, N.D. University of Agriculture \& Technology, Faizabad - 224 229, INDIA \\ ${ }^{4}$ Department of Genetics \& Plant Breeding, C.S.A. University of Agriculture \& Technology, Kanpur - 208 002, INDIA \\ *Corresponding author E-mail: vks.slay@gmail.com
}

Received: March 11,2015; Revised received: August 11, 2015; Accepted: January 1, 2016

\begin{abstract}
Twenty eight hybrids developed from eight genotypes of linseed through diallel mating design (excluding reciprocal) along with one checks viz., Shekhar were evaluated in randomized block design with three replications for eleven distinct morphological traits during rabi season of 2012-13, to estimate the general combining ability (GCA) of the parents and specific combining ability (SCA) of hybrids considered for the development of high yielding varieties. The analysis of variance for combining ability revealed significant mean sum of squares due to GCA and SCA for all the traits under study. Genotype EC-1392 (0.50) and TL-11 (0.45) has been found good general combiner with highest magnitude of GCA effects for seed yield per plant. In addition to above, EC-1392 and TL-11 also showed good GCA effects for plant height, secondary branches per plant, capsules per plant and biological yield per plant. Hybrids A.95.B x Shekhar (2.43), TL-11 x EC-1392 (1.71) and NDL-2004-05 x GS-234 (1.53) showed higher positive significant SCA effects for seed yield per plant. These hybrids also exhibited positive significant SCA effects for plant height, secondary brances per plant, capsules per plant, indicating potential for exploiting hybrid vigour in breeding programme.
\end{abstract}

Keywords: GCA, Linseed, SCA, Seed yield

\section{INTRODUCTION}

Oilseed crops occupy prestigious place in Indian agriculture due to their vital role in the sustainable economy of the country. Linseed (Linum usitatissimum L.) is an annual autogamous diploid $(2 x=2 n=30)$ oilseed crop belonging to Linaceae family, growing during rabi season in India. On the global scenario, India ranks second in terms of area after Canada. In terms of production, it occupies fourth place after Canada, China and USA, respectively. In India, it is grown in about 3.592 lakh ha area, contributing 1.465 lakh tonnes to the annual oilseed production of the country (Anonymous, 2013). Several countries have been growing linseed since long as a fibre crop and then in later stage it was cultivated for oil production. Linseed oil is best herbal source of omega- 3 and omega- 6 fatty acid, act as brain tonic kwon to cure the diseases like cardiovascular disease (CVDs), diabetes, rheumatoid arthritis, cancer and behavioral problem. Linseed oil is the richest source of lignin, a group of plant substance known as phytoestrogen-natural anticancer agent (Chauhan et al., 2009).

The success of any hybridization programme chiefly depends on combining ability of parents used in crossing programme (Hallauer and Miranda, 1981). Selection of superior segregants followed by the selection of the best ones are the basic tasks of any breeding process (Simmonds, 1989). This may be achieved on the basis of some objective criteria offered by the determination of the combining ability in parental forms used. To initiate an effective breeding programme, combining ability analysis is a powerful tool to identify parents with better potential to transmit desirable characteristics to the progenies and to identify the best specific crosses for yield parameters. Isolation of parental lines of good combining ability makes the pathway easy, towards the success. The concept of combining ability plays a significant role in crop improvement, as it helps the breeder to study and compare the performance of the new lines in hybrids combination. It provides the base to select good combiners and also to understand the nature of gene action. Moreover, the exploitation of heterosis is primarily dependent on the development of high per se performing lines with good general combining ability. Keeping the above fact in mind, the present study was, therefore, undertaken with a view to estimate general and specific combining 
ability variances and effects to identify superior hybrids with good yield potential.

\section{MATERIALS AND METHODS}

Experimental site and design: The experimental material consisted of eight diverse genotype viz., NDL 2004-05, R-552, TL-11, TL-27, EC-1392, A.95.B, GS234, Shekhar of linseed were crossed in all possible combinations using diallel mating design (excluding reciprocals) to obtain 28 hybrids of linseed, during rabi season of 2011-12 under irrigated, normal soil condition at the Genetics and Plant Breeding Research farm of N.D. University of Agriculture and Technology, Faizabad, India. These twenty eight hybrids, eight parents along with one standard checks were evaluated in randomized block design with three replications, in a single row plot of $3 \mathrm{~m}$ length, maintaining crop geometry of 30 x $15 \mathrm{~cm}$ in rabi 2012-13. All recommended agronomic practices were adopted in order to raise healthy crop.

Recording of data: The data were recorded from five randomly selected competitive plants o from each row on eleven distinct morphological characters, except days to 50 per cent flowering, days to maturity, where it was observed on complete plot basis. The data on plant height, primary branches per plant, secondary branches per plant, capsules per plant, seeds per plant, 1000-seed weight, biological yield per plant, seed yield per plant and harvest index were recorded for statistical analysis.

Statistical analysis: The mean value of the recorded data was subjected to analysis of variance using the statistical analysis procedures of Panse and Sukhatme, 1985. The combining ability analysis for diallel mating design was performed according to Method-II (parents and one set of $\mathrm{F}_{1}$,s without reciprocals) proposed by Griffing (1956).

\section{RESULTS AND DISCUSSION}

The analysis of variance for combining ability, using diallel mating design in respect of 28 crosses for all the eleven characters are presented in Table 1 and combining ability effect of seed yield and its component are presented in Tables 2 and 3.

Estimates of combining ability variance: The variances due to GCA and SCA were highly significant for all the characters. These results suggested the existence of additive and non-additive gene actions for various traits in the materials under study. The estimate component of variance for SCA was higher than GCA for all the characters except days to $50 \%$ flowering, days to maturity and 1000-seed weight, indicate predominance of non-additive gene action to control these characters. Highly significant values for both combining capabilities received by Mishra et al., (2013). Both general and specific combining ability were important but the former played an important role in the expression of all the characters.

Estimates of combining ability effects: The combining ability analysis was performed to obtain information on selection of better parents and crosses for their further use in breeding programme.

Table 1. Analysis of variance of combining ability of eleven characters in diallel crosses of linseed.

\begin{tabular}{|c|c|c|c|c|c|c|c|c|c|c|c|c|}
\hline $\begin{array}{l}\text { Source } \\
\text { of } \\
\text { varia- } \\
\text { tion }\end{array}$ & df. & $\begin{array}{l}\text { Days to } \\
50 \% \\
\text { flower- } \\
\text { ing }\end{array}$ & $\begin{array}{l}\text { Days to } \\
\text { matur- } \\
\text { ity }\end{array}$ & $\begin{array}{l}\text { Plant } \\
\text { heigh } \\
t(\mathrm{~cm})\end{array}$ & $\begin{array}{l}\text { Primary } \\
\text { branches } \\
\text { / plant }\end{array}$ & $\begin{array}{l}\text { Secon- } \\
\text { dary } \\
\text { branches/ } \\
\text { plant }\end{array}$ & $\begin{array}{l}\text { Cap- } \\
\text { sules/ } \\
\text { plant }\end{array}$ & $\begin{array}{l}\text { Seeds } \\
/ \\
\text { plant }\end{array}$ & $\begin{array}{l}1000 \\
\text { Seed } \\
\text { weigh } \\
t(g)\end{array}$ & $\begin{array}{l}\text { Biologi- } \\
\text { cal } \\
\text { yield/ } \\
\text { plant } \\
\text { (g) }\end{array}$ & $\begin{array}{l}\text { Seed } \\
\text { yield/ } \\
\text { plant } \\
\text { (g) }\end{array}$ & $\begin{array}{l}\text { Har- } \\
\text { vest } \\
\text { Index } \\
(\%)\end{array}$ \\
\hline GCA & 7 & $58.50 * *$ & $26.31 * *$ & $\begin{array}{c}62.71 \\
* *\end{array}$ & $0.32 * *$ & $17.54 * *$ & $\begin{array}{c}593.49 \\
* *\end{array}$ & 0.16 & $\begin{array}{c}2.41 * \\
*\end{array}$ & $7.79 * *$ & $1.19^{* *}$ & $\begin{array}{c}20.69 * \\
*\end{array}$ \\
\hline SCA & 28 & $12.25^{* *}$ & $6.71^{* *} *$ & $\begin{array}{c}17.19 \\
* *\end{array}$ & $0.39 * *$ & $31.74 * *$ & $\begin{array}{c}598.20 \\
* *\end{array}$ & $\begin{array}{c}0.24 * \\
*\end{array}$ & $\begin{array}{c}0.31 * \\
*\end{array}$ & $9.68 * *$ & $1.29^{* *}$ & $\begin{array}{c}26.21 * \\
*\end{array}$ \\
\hline Error & 70 & 1.83 & 2.14 & 1.01 & 0.05 & 2.16 & 18.24 & 0.08 & 0.01 & 0.34 & 0.05 & 2.40 \\
\hline
\end{tabular}

Table 2. Estimates of general combining ability (GCA) effects for eleven characters in linseed.

\begin{tabular}{|c|c|c|c|c|c|c|c|c|c|c|c|}
\hline Parents & $\begin{array}{l}\text { Days to } \\
50 \% \text { flow- } \\
\text { ering }\end{array}$ & $\begin{array}{l}\text { Days to } \\
\text { matur- } \\
\text { ity }\end{array}$ & $\begin{array}{c}\text { Plant } \\
\text { height } \\
(\mathrm{cm})\end{array}$ & $\begin{array}{c}\text { Pri- } \\
\text { mary } \\
\text { branch } \\
\text { es/ } \\
\text { plant }\end{array}$ & $\begin{array}{c}\text { Secon- } \\
\text { dary } \\
\text { branche } \\
\text { s/ plant }\end{array}$ & $\begin{array}{l}\text { Cap- } \\
\text { sule/ } \\
\text { plant }\end{array}$ & $\begin{array}{c}\text { Seeds/ } \\
\text { plant }\end{array}$ & $\begin{array}{c}1000 \\
\text { Seed } \\
\text { weight } \\
\text { (g) }\end{array}$ & $\begin{array}{c}\text { Biologi- } \\
\text { cal } \\
\text { yield/ } \\
\text { plant }(g)\end{array}$ & $\begin{array}{l}\text { Seed } \\
\text { yield/ } \\
\text { plant }\end{array}$ & $\begin{array}{c}\text { Har- } \\
\text { vest } \\
\text { index } \\
(\%)\end{array}$ \\
\hline $\begin{array}{c}\text { NDL-2004- } \\
05\end{array}$ & $-1.78 * *$ & $-1.70 * *$ & $-1.21 * *$ & $0.27 * *$ & $-1.04 *$ & $-3.72 * *$ & 0.12 & 0.04 & $-0.89 * *$ & $\begin{array}{c}- \\
0.24 * *\end{array}$ & $1.71 * *$ \\
\hline R-552 & $3.18 * *$ & $1.87 * *$ & $1.47 * *$ & -0.01 & -0.17 & $-9.87 * *$ & $-0.18 *$ & $0.24^{* *}$ & $-0.37 *$ & $-0.16^{*}$ & -0.12 \\
\hline TL-11 & 0.02 & 0.33 & $2.83^{* *}$ & 0.08 & $2.20 * *$ & $9.67 * *$ & -0.01 & $-0.28 * *$ & $1.09 * *$ & $0.45^{* *}$ & 0.14 \\
\hline TL27 & $-3.18 * *$ & $-1.70^{* *}$ & 0.38 & 0.05 & $1.00 *$ & $4.01 * *$ & -0.14 & $0.80^{* *}$ & 0.10 & 0.00 & 0.06 \\
\hline EC-1392 & $3.75 * *$ & $2.57 * *$ & $1.72 * *$ & 0.11 & 0.57 & $9.92^{* *}$ & 0.04 & $-0.74 * *$ & $1.22 * *$ & $0.50 * *$ & 0.74 \\
\hline A.95.B & 0.48 & 0.60 & -0.19 & -0.02 & 0.12 & 0.17 & -0.10 & $0.38^{* *}$ & 0.13 & -0.10 & $-2.74 * *$ \\
\hline GS-234 & $-1.52 * *$ & -0.70 & $-5.39 * *$ & $-0.31 * *$ & $-2.17 * *$ & $-9.80 * *$ & 0.10 & 0.05 & $-1.35^{* *}$ & $\overline{-}^{-}$ & $-1.22 * *$ \\
\hline Shekhar & $-0.95 *$ & $-1.27 * *$ & 0.38 & $-0.17 *$ & -0.51 & -0.39 & 0.16 & $-0.48 * *$ & 0.06 & 0.09 & $1.42 * *$ \\
\hline SE (gi) & 0.40 & 0.43 & 0.30 & 0.07 & 0.43 & 1.26 & 0.08 & 0.03 & 0.17 & 0.07 & 0.46 \\
\hline SE (gi-gj) & 0.60 & 0.65 & 0.45 & 0.10 & 0.66 & 1.91 & 0.13 & 0.05 & 0.26 & 0.10 & 0.69 \\
\hline
\end{tabular}

* and **Significant at 5 and 1 per cent level, respectively. 
Vivek Kumar Singh et al. / J. Appl. \& Nat. Sci. 8 (1) : 1-4 (2016)

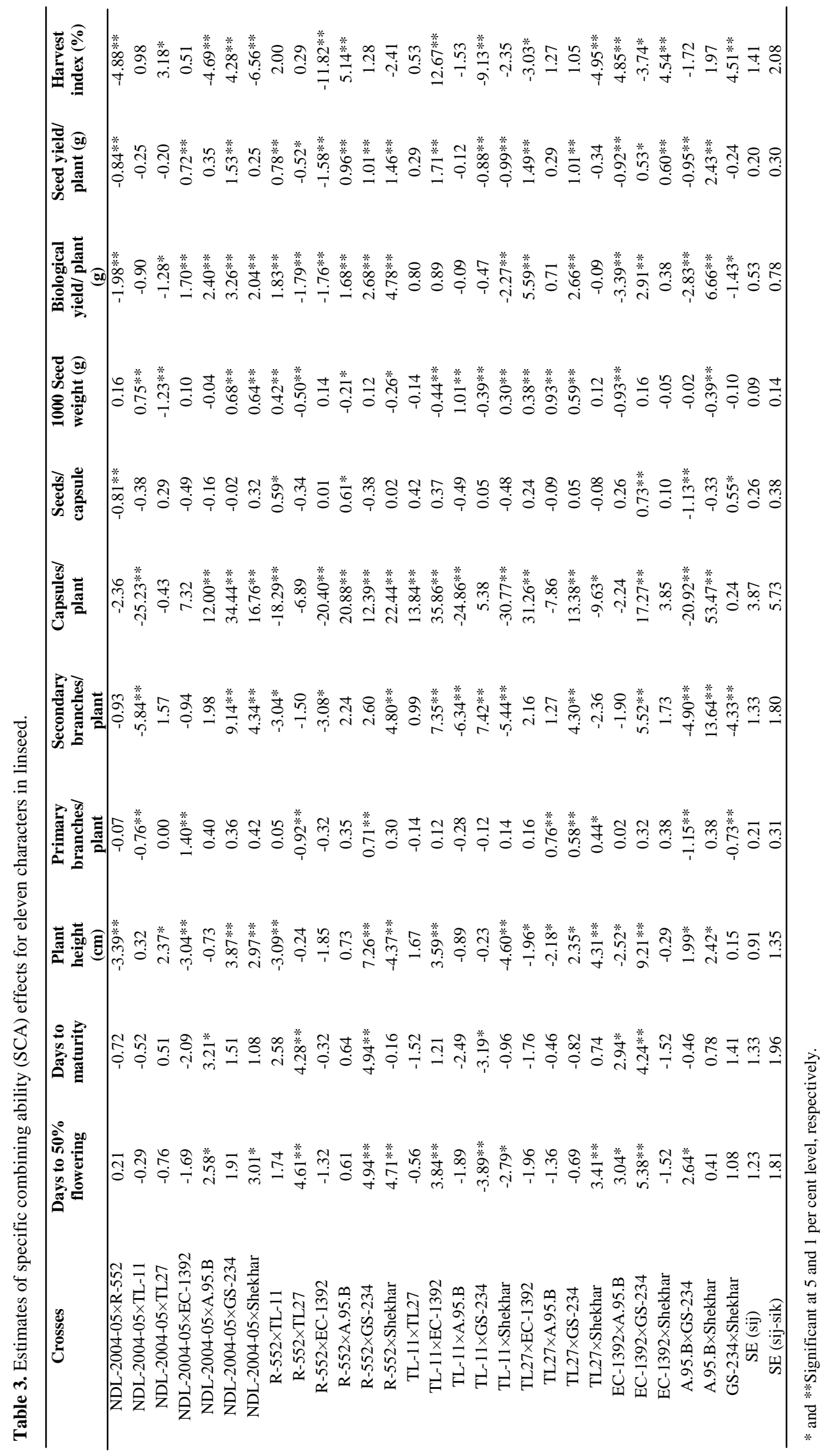


GCA effect: The estimate of GCA effects among the parental lines for yield and its component traits to identify the best parent for subsequent hybrid development programme Table 2. The estimates of GCA effects revealed that good general combiner for seed yield per plant were EC-1392 and TL-11. In addition to above trait, EC-1392 also good general combiner for days to 50 per cent flowering, days to maturity, plant height, capsule per plant and biological yield per plant; and TL-11 for plant height, secondary branches per plant, capsule per plant and biological yield per plant. This result indicate the preponderance of additive and additive $\mathrm{x}$ additive gene effects (Griffing, 1956 and Sprague and Tatum, 1942). Data on GCA effects indicated that effects varied significantly for different characters in different parents. Good general combining parent results in higher frequency of heterotic hybrids than poor combining parent (Sahu et al., 2013). The high GCA effects in desirable direction for yield and its contributing traits indicated that such lines would combine well with other lines to produce superior progeny.

SCA effect: Sprague and Tatum (1942) reported that the SCA effect is due to non-additive genetic proportion. The SCA effect is considered a reliable index for the identification of superior hybrid. Estimates of SCA effect of the hybrids for different characters are presented in Table 3.

Among the hybrids, A.95.B x Shekhar (2.43) showed highest significant SCA effects in positive direction for seed yield per plant followed by TL-11 x EC-1392 (1.71) and NDL-2004-05 x GS-234 (1.53). These hybrids also exhibited significant positive SCA effects for plant height, secondary branches per plant, number of capsules per plant, indicating potential for exploiting hybrid vigour in breeding programme. The cross combinations, TL-11 x GS-234 for days to $50 \%$ flowering, days to maturity, number of secondary branches per plant; EC-1392 x GS- 234, R-552 x GS234 and TL-27 x Shekhar for plant height; NDL-200405 x EC-1392, TL-27 x A.95.B and R-552 x GS-234 for number of primary branches per plant; A.95.B x Shekhar, NDL-2004-05 x GS-234 and TL-11 x GS234 for number of secondary branches per plant; A.95.B x Shekhar, TL-11 x EC-1392 and NDL-200405 x GS-234 for number of capsules per plant; EC1392 x GS- 234, R-552 x A.95.B and R-552 x TL-11 for number of seeds per capsule; TL-11 x A.95.B, TL27 x A.95.B and NDL-2004-05 x TL-11 for 1000-seed weight; A.95.B x Shekhar, TL-27 x A.95.B and R-552 $\mathrm{x}$ Shekhar for biological yield per plant; TL-11 x EC-
1392, NDL-2004-05 x GS-234 and EC-1392 x A.95.B for harvest index were the good specific combinations. Similar finding for identification of superior inbred lines and hybrids based on GCA and SCA effects for seed yield and its components in maize were also reported by Kaushal et al. (1974), Rai and Das (1974) and Neelam et al. (1981).

\section{Conclusion}

The hybrid A.95.B x Shekhar was the best specific combination for seed yield per plant followed by TL11 x EC-1392 and NDL-2004-05 x GS-234. These hybrids also showed significant positive SCA effects for plant height, secondary branches per plant, number of capsules per plant, indicating potential for exploiting hybrid vigour in breeding programme.

\section{REFERENCES}

Anonymous, (2013). Annual Progress Report, All India Coordinated Research Project on Linseed. Project Coordinating Unit (Linseed), CSAUA\&T, Kanpur.

Chauhan, M.P., Shadhana, S. and Singh, A.K. (2009). Postharvest uses of Linseed. J. Hum. Eco., 28 (3): 217-219.

Griffing, B. (1956). Concept of general and specific combining ability.Aust. J. Biol. Sci., 9: 463-493.

Hallauer, A.R. and Miranda, J.B. (1981). Quantitative Genetics in Maize Breeding, Iowa State University Press Ames, Iowa, USA.

Kaushal, P.K., Srivastava, S.R. and Goswami, U. (1974). Combining ability for oil content in linseed. Indian $J$. Agric. Sci., 44: 859-862.

Mishra, R.K., Marker, S., Bhatnagar, V. and Mahto, D. (2013). Combining ability and heterosis for seed yield and its component in linseed (Linum usitatissimum L.). Adv. Plant Sci., 2 (1): 44-47.

Neelam, Singh, S.P. and Singh, C.B. (1981). Genetic analysis of seed yield and yield contributing characters in linseed using line $\mathrm{x}$ tester analysis. Indian J. agric. Sci., 51 (7): 483-488.

Panse, V.G. and Sukhatme, P.V. (1985). Statistical methods for Agricultural workers. IInd Ed. I.C.A.r., New Delhi.

Rai, M. and Das K. (1974). Combining ability for components of yield in linseed. Indian J. Genet., 34: 371-375.

Sahu, V., Singh, S.K., Sharma, Amita and Bhati, P.K. (2013). Combining ability analysis for yield and yield traits using 'wa' cytoplasm in rice (Oryza sativa L.). The Bioscan., 8 (3): 871-874.

Simmonds, N.W. (1989). How frequent are superior genotypes in plant breeding populations. Biol. Rev., 64: 341365.

Sprague, G.F. and Tatum, L.A. (1942). General vs specific combining ability in single cross of corn. Jour. Amer. Soc. Agron., 34: 923-32. 